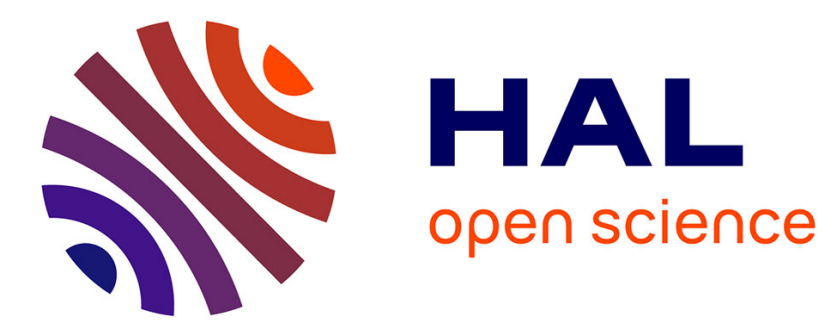

\title{
Up to $92 \%$ increase of cancer-preventing lunasin in organic spring barley
}

Linda Legzdina, Ilva Nakurte, Inga Kirhnere, Jana Namniece, Liga Krigere, Kristine Saleniece, Indra Beinarovica, Ruta Muceniece

\section{To cite this version:}

Linda Legzdina, Ilva Nakurte, Inga Kirhnere, Jana Namniece, Liga Krigere, et al.. Up to 92 \% increase of cancer-preventing lunasin in organic spring barley. Agronomy for Sustainable Development, 2014, 34 (4), pp.783-791. 10.1007/s13593-013-0203-4 . hal-01234823

\section{HAL Id: hal-01234823 \\ https://hal.science/hal-01234823}

Submitted on 27 Nov 2015

HAL is a multi-disciplinary open access archive for the deposit and dissemination of scientific research documents, whether they are published or not. The documents may come from teaching and research institutions in France or abroad, or from public or private research centers.
L'archive ouverte pluridisciplinaire HAL, est destinée au dépôt et à la diffusion de documents scientifiques de niveau recherche, publiés ou non, émanant des établissements d'enseignement et de recherche français ou étrangers, des laboratoires publics ou privés. 


\title{
Up to $92 \%$ increase of cancer-preventing lunasin in organic spring barley
}

\author{
Linda Legzdina • Ilva Nakurte • Inga Kirhnere • \\ Jana Namniece • Liga Krigere • Kristine Saleniece • \\ Indra Beinarovica $\cdot$ Ruta Muceniece
}

Accepted: 26 November 2013 /Published online: 8 January 2014

(C) INRA and Springer-Verlag France 2013

\begin{abstract}
Lunasin is a plant peptide that has health benefits such as cancer-preventing, antioxidant, anti-inflammatory, and cholesterol-lowering effects. However, there is actually no information on the influence of cropping on the lunasin content of cereals. Therefore, we studied lunasin in 22 spring barley genotypes grown both organically and conventionally during two seasons. We found that lunasin content of barley grain averaged $44.8 \mu \mathrm{g} / \mathrm{g}$, ranging from 5.0 to $189.0 \mu \mathrm{g} / \mathrm{g}$. Organic farming increased average lunasin content by 47 $92 \%$. Ten out of 22 genotypes produced significantly more lunasin under organic farming in both years. Our findings evidence positive effects of organic farming on lunasin content in barley.
\end{abstract}

Keywords Lunasin - Organic agriculture · Conventional agriculture $\cdot$ Spring barley $\cdot$ Genotype $\times$ environment interaction $\cdot$ Heritability

\section{Introduction}

Lunasin is a novel peptide originally identified in soybean (Galvez and de Lumen 1999) and meanwhile also found in cereals, barley (Jeong et al. 2002, 2010a), wheat (Jeong et al. 2007a), rye (Jeong et al. 2009), triticale (Nakurte et al. 2012),

L. Legzdina $(\bowtie) \cdot$ I. Kirhnere $\cdot$ I. Beinarovica

State Priekuli Plant Breeding Institute, Zinatnes Str. 1a,

Priekuli 4126, Latvia

e-mail: Linda.Legzdina@priekuliselekcija.lv

I. Nakurte

Faculty of Chemistry of University of Latvia, Kr.Valdemara Str. 48,

Riga 1013, Latvia

J. Namniece $\cdot$ L. Krigere $\cdot$ K. Saleniece $\cdot$ R. Muceniece Faculty of Medicine, University of Latvia, Sarlotes Str. 1a, Riga 1001, Latvia and oat (Nakurte et al. 2013), as well as non-cereals, e.g., amaranth (Silva-Sánchez et al. 2008) and Solanum nigrum (Jeong et al. 2007b). The presence of the lunasin peptide has been reported in many soybean varieties, with concentrations ranging from 4.4 to $70.5 \mathrm{mg} / \mathrm{g}$ of protein or 0.5 to $8.1 \mathrm{mg} / \mathrm{g}$ of seed (de Mejia et al. 2004; de Lumen 2005). In cereals, the lunasin content ranged from 13.6 to $21.5 \mu \mathrm{g} / \mathrm{g}$ in barley (Jeong et al. 2002), 211-249 $\mu \mathrm{g} / \mathrm{g}$ in wheat (Jeong et al. 2007a), 50 $150 \mu \mathrm{g} / \mathrm{g}$ (Jeong et al. 2009) and 732-1510 $\mu \mathrm{g} / \mathrm{g}$ in rye, 429 $6,458 \mu \mathrm{g} / \mathrm{g}$ in triticale (Nakurte et al. 2012), and 64-197 $\mu \mathrm{g} / \mathrm{g}$ in oat (Nakurte et al. 2013).

Recent scientific evidence indicates that lunasin has antioxidant, anti-inflammatory, and cholesterol-lowering effects (Hernández-Ledesma et al. 2009, 2013) and has influence on central nervous system (CNS) (Dzirkale et al. 2013). Studies in animals have shown that lunasin can be administered orally and can enter target tissues (de Lumen 2005; Jeong et al. 2009). Findings obtained on the bioavailability, bioactivity, and thermostability of lunasin support the inclusion of lunasin-containing products in the human diet (Park et al. 2005; Jeong et al. 2010a). Synthetic lunasin and that isolated from soybean were first investigated as a factor that might prevent cancer cells from dividing and multiplying. Anticarcinogenic activity of the lunasin has been demonstrated both in in vitro and in vivo assays (Hernández-Ledesma et al. 2013). Lunasin is also a valuable peptide for the cardiovascular system. It has been reported to lower serum low density lipoprotein (LDL) cholesterol levels by selectively disrupting a necessary step in the production of a key enzyme, 3hydroxy-3-methyl-glutaryl-CoA reductase, and by upregulating the expression of the LDL-receptor gene (HernándezLedesma et al. 2009). Recent data show that internalization of lunasin into macrophages is amplified in inflammatory conditions and is primarily mediated by endocytic mechanisms that involve integrin signaling, clathrin-coated structures, and macropinosomes. Lunasin may be responsible for 
attenuation of cardiovascular diseases risk factors by interacting with pathways involved in endocytosis and inflammation (Cam et al. 2013). We (Nakurte et al. 2013) and other authors (Jeong et al. 2010b; Hernández-Ledesma et al. 2013) have shown that lunasin isolated from plants exerts antioxidant effects similarly to the synthetic lunasin. Effects of the synthetic lunasin on CNS were described as markedly expressed neuroleptic/cataleptic action in male C57Bl/6 mice (Dzirkale et al. 2013). The authors suggest that the action of lunasin at least partially is provided via dopaminergic D1 receptor pathways.

Although several publications indicate that the lunasin content in crops depends on the genotype (Wang et al. 2008; Nakurte et al. 2012, 2013), very limited information is available with regard to the influence of the growing environment on the content of lunasin in crops. The effect of temperature and soil moisture on lunasin in soybean was reported (Wang et al. 2008), but no data on cereals are available to date.

Since the end of the last century, the market for organic products has grown. Organic farming is continuously becoming a widespread form of agriculture, and organic products are increasingly being requested by consumers. Additionally, people have shown a growing interest in food containing phytochemicals, commonly known as functional food. Conventional, organic, and integrated agricultural practices may induce differences in the plant phytochemical content; higher amounts of phytochemicals are usually produced in stressful growing conditions and farmers are challenged to achieve both crop yield and benefit for health (García-Mier et al. 2013). Many studies consistently report a lack of significant differences between organically and conventionally grown food in terms of safety and nutritional value, suggesting that crops and livestock products produced in both farming systems are comparable with regard to their nutrient content (Smith-Spangler et al. 2012). Nevertheless, the results obtained are contradictory: some authors report no significant differences, yet many studies have shown different amounts of nutritionally important and health-promoting compounds in crops grown under organic and conventional management (Woese et al. 1997; Worthington 2001; Bour and Prescott 2002; Magkos et al. 2003).

Interest in research on the content of biologically active substances in organic farming has increased dramatically (Huber et al. 2011). For instance, Benbrook (2005) estimated that the content of biologically active compounds is, on average, $30 \%$ higher in organically grown plants in comparison to those grown conventionally. In most studies, the content of vitamin $\mathrm{C}$ was found to be significantly higher in an organic farming system (Worthington 2001). However, the carotenoid content in potato was found not to be influenced by organic and conventional farming systems (Murniece et al. 2012), whereas the level of carotenoids in other vegetables and fruits was higher when they were grown organically (Huber et al.
2011). The majority of studies have reported a higher content of phenolic compounds in organically grown fruits, vegetables (Huber et al. 2011), and potatoes (Lombardo et al. 2012); organically generated products contain higher amounts of flavonoids, which are important antioxidants (Koh et al. 2008; Carbonaro and Mattera 2001).

To our best knowledge, no data about differences in the lunasin content of organic and conventional crops were published so far.

Therefore, the aim of this study was to compare the content of lunasin peptide in the grain of organically and conventionally grown spring barley genotypes and to estimate the effect of the genotype and environment.

\section{Material and methods}

\subsection{Barley genotypes and experimental conditions}

A total of 22 spring barley varieties and breeding lines differing in their plant morphological characteristics, origin, and year of registration (Table 1) were grown in field trials under organic and conventional management in Priekuli (lat. 57 $19^{\prime}$ N, long. $25^{\circ} 20^{\prime} \mathrm{E}$ ). Eight of the genotypes were selected for organic farming. The experiment was conducted during 2010 and 2011 in $6.5 \mathrm{~m}^{2}$ plots with three replications and a randomized complete block design.

The trials were arranged on sod-podzolic loamy sand; the soil properties are summarized in Table 2. In the conventional field, the precrop was potato. Mineral fertilizer before sowing at $80-83 \mathrm{~kg} / \mathrm{ha} \mathrm{N}, 45-48 \mathrm{~kg} / \mathrm{ha}_{2} \mathrm{O}_{5}$, and $75-84 \mathrm{~kg} / \mathrm{ha} \mathrm{K}_{2} \mathrm{O}$; the herbicide Secator $(100 \mathrm{~g} / \mathrm{L}$ amidosulfuron and $25 \mathrm{~g} / \mathrm{L}$ iodosulfuran) at $0.15 \mathrm{~L} / \mathrm{ha}$; and insecticide Karate Zeon 5 m.s. (50 g/L lambda-cyhalothrin) at $0.15 \mathrm{~L} /$ ha were applied. In the organic field, the precrop was pea for green manure grown as main season crop. Weed control was performed by harrowing at the beginning of the tillering stage.

The grain yield was assessed by combine harvest of the whole plots after cleaning with $1.5 \mathrm{~mm}$ sieve and recalculating to a $14 \%$ moisture content; the test weight, content of crude protein, and $(1 \rightarrow 3)$ and $(1 \rightarrow 4) \beta$-D-glucans (beta-glucans) in the dry matter were determined using a Infratec 1241 Near-Infrared Transmittance grain analyzer (Foss, Högenäs, Sweden).

The meteorological conditions were, in general, favorable for barley development in both years. The mean air temperature during the barley vegetation period surpassed the longterm average $\left(14.1^{\circ} \mathrm{C}\right)$ by 2.6 and $2.4^{\circ} \mathrm{C}$ in 2010 and 2011, respectively, resulting in a comparatively early maturity. In 2010, the amount of rainfall was $143 \%$ of the long-term average $(221.7 \mathrm{~mm})$, which promoted lodging in the conventional field, whereas the precipitation was close to the average (93\%) in 2011. 
Table 1 Barley genotypes included in the study
${ }^{\text {a }}$ ISO 3166-1-alpha-2 code

${ }^{\mathrm{b}}$ Organic farming

\begin{tabular}{|c|c|c|c|c|}
\hline $\begin{array}{l}\text { Variety, } \\
\text { breeding line }\end{array}$ & $\begin{array}{l}\text { Country } \\
\text { of origin }\end{array}$ & Pedigree & $\begin{array}{l}\text { Year of first } \\
\text { release }\end{array}$ & $\begin{array}{l}\text { Specific } \\
\text { information }\end{array}$ \\
\hline Abava & $\mathrm{LV}^{\mathrm{a}}$ & Mari/Elsa//Domen & 1978 & \\
\hline Annabell & $\mathrm{DE}$ & 90014-DH/Krona & 1999 & \\
\hline Anni & $\mathrm{EE}$ & Lola/Lisa & 1991 & \\
\hline BZ12-83 & LV & Primus/Idumeja & & Selected under $\mathrm{OF}^{\mathrm{b}}$ \\
\hline BZ14-12 & LV & Anni/Dziugiai & & Selected under OF \\
\hline BZ14-99 & LV & Anni/Dziugiai & & Selected under OF \\
\hline Dziugiai & LT & & 1947 & \\
\hline Idumeja & LV & Imula/Ida & 2000 & Early maturity \\
\hline Inari & FI & JO-1263/Triumph & 1994 & \\
\hline Irbe & LV & Filippa/CDC McGwire//Kristaps & 2011 & Hulless barley \\
\hline PR-3605 & LV & $\begin{array}{l}\text { Rūja/Prestige/3/L-2233//Linus/ } \\
\text { Annabell }\end{array}$ & & \\
\hline PR-4121 & LV & Tunika/L-3118 & & \\
\hline PR-4181 & LV & Hydrogen/H-155 & & \\
\hline PR-4407 & LV & Roxane/Danuta//Idumeja & & \\
\hline PR-4812 & LV & Rubiola/L-3118 & & Selected under OF \\
\hline PR-4814 & LV & Danuta/L-3008//Rubiola & & Selected under OF \\
\hline PR-4825 & LV & Abava/Annabell & & \\
\hline PR-5145 & LV & Peggy/L-3118//Rubiola & & Selected under OF \\
\hline Primus & SE & & 1901 & Tall plants, late maturity \\
\hline Rasa & LV & Frankengold/KM-R-54/72 & 1996 & \\
\hline Rubiola & LV & Rūja/Run8/458 & 2011 & Recommended for OF \\
\hline Vienna & AT & & 2007 & Registered for OF \\
\hline
\end{tabular}

In 2010, in the conventional field, an unusually high infection level of Barley Yellow Dwarf Virus was observed (average score of 5.7, range of 2.3-8.3; scale from $0=0 \%$ to $9=$ $100 \%$ infection level).

\subsection{Materials and reagents}

Acetonitrile, methanol and hexane, both gradient grade, formic acid ( $\geq 99 \%$ ), trifluoroacetic acid ( $\geq 99 \%$ ), and protease cocktail were supplied by Sigma-Aldrich. The water used in this work was purified using a Milli-Q water purification system from Millipore. The standard for synthetic lunasin was purchased from CASLO Laboratory ApS (c/o Scion Denmark Technical University, Lyngby, Denmark), and working

Table 2 Soil agrochemical properties at the study site

\begin{tabular}{llllll}
\hline Soil characteristics & 2010 & & & 2011 \\
\cline { 2 - 3 } \cline { 5 - 6 } \cline { 5 - 6 } & Organic & Conventional & & Organic & Conventional \\
\hline pH KCL & 5.7 & 5.5 & 5.4 & 5.4 \\
Humus content, \% & 2.8 & 2.6 & & 2.1 & 3.0 \\
$\mathrm{~K}_{2} \mathrm{O}, \mathrm{mg} / \mathrm{kg}$ & 144 & 132 & & 98 & 165 \\
$\mathrm{P}_{2} \mathrm{O}_{5}, \mathrm{mg} / \mathrm{kg}$ & 111 & 100 & & 116 & 187 \\
\hline
\end{tabular}

solutions were prepared before the sample analyses. Standard addition method was used to solve the matrix effect problem by diluting the stock solution with sample solution of known concentration of the lunasin. The stock solution of the standard at a concentration of $40 \mu \mathrm{g} / \mathrm{mL}$ was prepared by dissolving the peptide in water and storing at $4{ }^{\circ} \mathrm{C}$.

\subsection{Instrumentation}

The chromatographic analysis was performed using a modular high-performance liquid chromatography (HPLC) system, Waters 2690 Alliance, consisting of quaternary pump, autosampler, and column thermostat, coupled to an electrospray ionization tandem mass spectrometer (Waters Micromass Quattro Micro ${ }^{\text {TM }}$ API (Atmospheric Pressure Ionization)). The HPLC separations were achieved using a reverse-phase Phenomenex Synergi Hydro-RP $4 \mu \mathrm{m}$, (150× $2.0 \mathrm{~mm}$ inner diameter) analytical column $\left(30^{\circ} \mathrm{C}\right)$, with a mobile phase composed of $0.1 \%$ formic acid in water (A) and $0.1 \%$ formic acid in acetonitrile (B) in gradient mode at a flow rate $300 \mu \mathrm{L} / \mathrm{min}$. The separation of the peptide was accomplished using a linear gradient of 20 to $60 \% \mathrm{~B}$ over $8.0 \mathrm{~min}$, $60 \%$ B was maintained for $3.0 \mathrm{~min}$, followed by $60-20 \%$ for another $1.0 \mathrm{~min}$, and $20 \% \mathrm{~B}$ was maintained for $8.0 \mathrm{~min}$ to reach the initial conditions. The injection volume was $50 \mu \mathrm{L}$. 
The quadrupole protonated molecular ion, with $\mathrm{m} / z 1258$ for lunasin, was detected by single-ion recording. The mass spectra were measured using a Micromass Quatro Micro triplequadrupole spectrometer equipped with an electrospray ionization source. The analyses were performed in the positive ion mode. The source temperature was $120{ }^{\circ} \mathrm{C}$, and the desolvation temperature was $250{ }^{\circ} \mathrm{C}$. Nitrogen was used as the nebulizing gas $(600 \mathrm{~L} / \mathrm{h})$. The electrospray capillary was set at $3.0 \mathrm{kV}$. The mass spectrometry analyses were performed at a cone voltage of $60 \mathrm{~V}$. The data analyses were performed using MasLynx version 4.1 software (Waters Corporation).

\subsection{Measurement of lunasin content}

Reverse-phase chromatography coupled to an electrospray ionization source was used to separate and ionize lunasin. The grain samples were pooled over the three field replications in equal amounts and ground using a Falling number Laboratory mill 3100 (Perten Instruments) with a 0.6-mm sieve. To isolate lunasin, we used an assay similar to that of Jeong et al. (2007a) and Nakurte et al. (2012).

In brief, $5 \mathrm{~g}$ of flour was extracted with $50 \mathrm{~mL}$ of $0.1 \mathrm{M}$ phosphate-buffered saline buffer, $\mathrm{pH} 7.4$, supplemented with fresh protease inhibitor cocktail (Sigma, St. Louis, USA) at a concentration of $1 \% v / v$ by stirring on a magnetic stirrer for $48 \mathrm{~h}$ at $4{ }^{\circ} \mathrm{C}$. The extract was centrifuged at $15,000 \mathrm{rpm}$ for $30 \mathrm{~min}$ at $4{ }^{\circ} \mathrm{C}$, and the supernatants were collected. The mixture was transferred to a new tube and twice extracted with $20 \mathrm{~mL}$ of hexane and cleared by centrifugation $(15,000 \mathrm{rpm}$ for $5 \mathrm{~min})$. The upper layer was discarded, and the lower layer was purified by solid-phase extraction (SPE) using Strata X $3 \mathrm{~mL}, 60 \mathrm{mg}$ (Phenomenex) cartridges. The SPE columns were pretreated with $3.0 \mathrm{~mL}$ of methanol, followed by $3.0 \mathrm{~mL}$ of water and sample. The column was washed with $3.0 \mathrm{~mL}$ of $0.1 \%$ formic acid in water, and $0.1 \%$ trifluoroacetic acid in $50 \%$ acetonitrile $(3.0 \mathrm{~mL})$ was used to elute the analytes from the extraction column. The eluate was dissolved 1:1 $(v / v)$ with mobile phase A and injected in the liquid chromatography-mass spectrometry/mass spectrometry system. Measurement for each sample was performed in three technical replications.

\subsection{Data analysis}

Analysis of variance (ANOVA) was carried out using GENSTAT 14.0 (2011); data of the three technical replications were submitted, and model GENOTYPE (G)+MANAGEMENT SYSTEM $(\mathrm{M})+\mathrm{YEAR}(\mathrm{Y})+\mathrm{G} \times \mathrm{Y}+\mathrm{G} \times \mathrm{M}+\mathrm{Y} \times \mathrm{M}+$ $\mathrm{G} \times \mathrm{Y} \times \mathrm{M}$ was applied. Partitioning of sum of squares was calculated from the ANOVA for each factor and their interaction as percentage from the total.

To estimate stability of lunasin concentration, ecovalence $\left(W_{\mathrm{i}}\right)$ was computed using Microsoft Excel software as described by Becker and Léon (1988) and expressed in percentage of the total interaction sum of squares.

Pearson phenotypic correlation coefficients were calculated using Microsoft Excel between the values of lunasin in both management systems and between lunasin and the plant traits assumed to influence lunasin, i.e., grain yield, thousand grain weight, grain test weight, beta-glucans, and crude protein content for each environment; correlation between lunasin and Barley Yellow Dwarf Virus infection score under conventional management in 2010 was calculated.

The broad-sense heritability was estimated from the variance components using the following formula:

$h^{2}=100 V_{g} /\left(V_{g}+V_{g m} / m+V_{g y} / y+V_{g m y} / m y+V_{e} / r m y\right)$

where $V_{g}$ is the genotypic variance, $V_{g m}$ is the variance of genotype $\times$ management system interaction, $V_{g y}$ is the variance of genotype $\times$ year interaction, $V_{g m y}$ is the variance of genotype $\times$ management system $\times$ year interaction, $V_{e}$ is the error variance, $r$ is the number of replications, $m$ is the number of management systems, and $y$ is the number of years;

$$
\begin{aligned}
& V_{g}=\left(\mathrm{MS}_{g}-\mathrm{MS}_{g m}-\mathrm{MS}_{g y}-\mathrm{MS}_{g m y}\right) / r m y \\
& V_{g m}=\left(\mathrm{MS}_{g m}-\mathrm{MS}_{g m y}\right) / r y \\
& V_{g y}=\left(\mathrm{MS}_{g y}-\mathrm{MS}_{g m y}\right) / r m \\
& V_{g m y}=\left(\mathrm{MS}_{g m y}-\mathrm{MS}_{e}\right) / r \\
& V_{e}=\mathrm{MS}_{e}
\end{aligned}
$$

where MS is the respective mean square from the ANOVA.

\section{Results and discussion}

\subsection{Range of lunasin content and effect of genotype}

The content of lunasin in the individual barley grain samples ranged from 5.0 to $189.0 \mu \mathrm{g} / \mathrm{g}$ (Table 3).

The effect of the genotype on the lunasin content was significant (Table 4). The mean lunasin content in both management systems and in both years significantly surpassed the average value of the respective environment for four genotypes, 'Dziugiai,' 'Idumeja,' 'Rubiola,' and PR-4121, whereas it was below the average for nine genotypes. A low lunasin content of $10 \mu \mathrm{g} / \mathrm{g}$ and less in all environments was registered for varieties 'Rasa' and 'Inari.' Jeong et al. (2009) showed that lunasin was present in 15 out of 21 cultivars of rye analyzed. Such varying amounts of lunasin in different rye genotypes grown in identical conditions confirm that genotype is a primary determinant of the composition of plant secondary metabolites. 
Table 3 Lunasin content (micrograms per gram) in barley grain during 2010-2011 in organic (O) and conventional $(\mathrm{C})$ management systems and ecovalence $\left(W_{\mathrm{i}} \%\right)$ over all environments and over organic and conventional management systems
The mean values of the respective genotype marked with a different letter $(a, b)$ are significantly different between the management systems $(p<0.05)$ within the respective year; the mean values significantly above or below the average value of all genotypes ( $p$ $<0.05$ ) in the respective column are marked with "+" and "-,"respectively; $\mathrm{LSD}_{0.05}=6.22$ when comparing means with the same level of year and management system; $\mathrm{LSD}_{0.05}=6.14$ for other comparisons; minimum and maximum values of the column are shown in italics

\begin{tabular}{|c|c|c|c|c|c|c|c|}
\hline \multirow[t]{2}{*}{ Genotype } & \multicolumn{2}{|l|}{2010} & \multicolumn{2}{|l|}{2011} & \multirow[t]{2}{*}{$W_{\mathrm{i}} \%$} & \multirow[t]{2}{*}{$W_{\mathrm{i}} \% \mathrm{O}$} & \multirow[t]{2}{*}{$W_{\mathrm{i}} \% \mathrm{C}$} \\
\hline & $\mathrm{O}$ & $\mathrm{C}$ & $\mathrm{O}$ & $\mathrm{C}$ & & & \\
\hline Abava & $34.2 \mathrm{a}-$ & $27.1 \mathrm{~b}$ & $31.4 \mathrm{a}-$ & $20.5 b-$ & 0.80 & 1.22 & 1.58 \\
\hline Annabell & $84.1 \mathrm{a}+$ & $18.7 \mathrm{~b}-$ & $79.8 \mathrm{a}+$ & $22.9 \mathrm{~b}-$ & 3.25 & 1.60 & 1.00 \\
\hline Anni & $17.3-$ & $19.1-$ & $19.5 \mathrm{~b}-$ & $92.3 \mathrm{a}+$ & 10.57 & 0.29 & 3.52 \\
\hline BZ12-83 & $9.9-$ & $10.0-$ & $11.3-$ & $14.6-$ & 1.21 & 0.39 & 0.40 \\
\hline BZ14-12 & $7.4 \mathrm{~b}-$ & $17.3 \mathrm{a}-$ & $13.5 \mathrm{~b}-$ & $54.6 \mathrm{a}+$ & 5.05 & 0.01 & 1.75 \\
\hline BZ14-99 & $13.6-$ & $9.1-$ & $23.7 \mathrm{a}-$ & $12.4 \mathrm{~b}-$ & 0.50 & 0.12 & 0.34 \\
\hline Dziugiai & $108.6 \mathrm{a}+$ & $82.3 b+$ & $95.4 b+$ & $168.0 \mathrm{a}+$ & 9.66 & 5.11 & 22.12 \\
\hline Idumeja & $61.3 b+$ & $80.7 \mathrm{a}+$ & $72.6+$ & $73.1+$ & 2.41 & 0.24 & 12.58 \\
\hline Inari & $5.0-$ & $8.0-$ & $5.1-$ & $5.0-$ & 1.39 & 0.60 & 0.24 \\
\hline Irbe & $24.7-$ & $19.1-$ & $19.1 \mathrm{~b}-$ & $30.3 \mathrm{a}-$ & 1.37 & 2.00 & 1.19 \\
\hline PR-3605 & $12.0-$ & $10.0-$ & $13.3-$ & $9.2-$ & 0.93 & 0.40 & 0.34 \\
\hline PR-4121 & $151.3 \mathrm{a}+$ & $131.6 \mathrm{~b}+$ & $156.0 \mathrm{~b}+$ & $189.0 \mathrm{a}+$ & 3.58 & 0.06 & 42.05 \\
\hline PR-4181 & $68.9 \mathrm{a}+$ & $11.7 \mathrm{~b}-$ & $80.6 \mathrm{a}+$ & $16.2 b-$ & 3.07 & 0.28 & 0.50 \\
\hline PR-4407 & $99.8 \mathrm{a}+$ & $18.2 \mathrm{~b}-$ & $139.0 \mathrm{a}+$ & $15.6 \mathrm{~b}-$ & 14.12 & 13.06 & 0.84 \\
\hline PR-4812 & $23.9 \mathrm{a}-$ & $3.5 \mathrm{~b}-$ & $16.7 \mathrm{a}-$ & $6.6 \mathrm{~b}-$ & 0.38 & 2.49 & 0.12 \\
\hline PR-4814 & $30.9 \mathrm{a}-$ & $14.4 \mathrm{~b}-$ & $36.0 \mathrm{a}-$ & $10.7 \mathrm{~b}-$ & 0.28 & 0.05 & 0.56 \\
\hline PR-4825 & $47.0 \mathrm{a}$ & $12.8 \mathrm{~b}-$ & $54.5 \mathrm{a}$ & $20.8 b-$ & 0.31 & 0.00 & 0.62 \\
\hline PR-5145 & $86.3 \mathrm{a}+$ & $13.4 \mathrm{~b}-$ & $166.0 \mathrm{a}+$ & $19.4 \mathrm{~b}-$ & 20.56 & 66.55 & 0.63 \\
\hline Primus & $10.1-$ & $13.0-$ & $18.0-$ & $13.9-$ & 1.06 & 0.01 & 0.53 \\
\hline Rasa & $5.0-$ & $7.0-$ & $8.0-$ & $10.0-$ & 1.25 & 0.20 & 0.24 \\
\hline Rubiola & $169.3 \mathrm{a}+$ & $61.8 \mathrm{~b}+$ & $178.1 \mathrm{a}+$ & $69.2 \mathrm{~b}+$ & 14.77 & 0.04 & 8.42 \\
\hline Vienna & $78.9 a+$ & $11.3 \mathrm{~b}-$ & $65.5 \mathrm{a}+$ & $12.3 \mathrm{~b}-$ & 3.48 & 5.26 & 0.43 \\
\hline Average & 52.3 & 27.3 & 59.2 & 40.3 & & & \\
\hline
\end{tabular}

The range of lunasin content in the barley genotypes analyzed in this study was larger than that reported by Jeong et al. (2002), showing that the genetic diversity of barley is considerably wider than previously supposed. The mean lunasin content value in our experiment was $44.8 \mu \mathrm{g} / \mathrm{g}$, but the maximal value was $189.0 \mu \mathrm{g} / \mathrm{g}$. In comparison with other cereals, this value was slightly less than that reported for wheat (Jeong et al. 2007a; Nakurte et al. 2012) and was similar to that for rye reported by Jeong et al. (2009) and oat reported by us (Nakurte et al. 2013) but considerably less than found in rye

Table 4 Partitioning of the sum of squares, mean square, and significance of the genotype $(\mathrm{G})$, management system $(\mathrm{M})$, year $(\mathrm{Y})$, and their interaction affecting the lunasin content in barley grain

\begin{tabular}{|c|c|c|c|c|c|}
\hline G & M & $\mathrm{Y}$ & $\mathrm{G} \times \mathrm{M}$ & $\mathrm{G} \times \mathrm{Y}$ & $\mathrm{G} \times \mathrm{M} \times \mathrm{Y}$ \\
\hline \multicolumn{6}{|c|}{ Partitioning of sum of squares, $\%$} \\
\hline 68.41 & 5.21 & 1.08 & 19.36 & 2.21 & 3.22 \\
\hline \multicolumn{6}{|c|}{ Mean square } \\
\hline 19917 & 31826 & 6615 & 5636 & 642 & 938 \\
\hline \multicolumn{6}{|l|}{$p$ value } \\
\hline$<0.001$ & $<0.001$ & $<0.001$ & $<0.001$ & $<0.001$ & $<0.001$ \\
\hline
\end{tabular}

and triticale grown under similar conditions in Latvia (Nakurte et al. 2012).

The broad-sense heritability for the lunasin content was $70.4 \%$. Correlations between the lunasin content in both systems and in both harvest years were significant in all cases, $p<0.01$, except $p<0.05$ for the correlation between the organic and conventional systems in 2011. The correlation coefficients were the highest between both years in each management system (0.94 for organic and 0.90 for conventional) and ranged between 0.44 and 0.69 in the other cases. The possibility of selecting and breeding soybean with a high lunasin content due to the noticeable variation of lunasin concentrations was suggested by Hernández-Ledesma et al. (2009). The comparatively large effect of the genotype, significant correlations between the lunasin content in different environments, and the high broad-sense heritability estimate also support the possibility of selecting and breeding lunasin-rich barley genotypes.

Although barley is not as rich in lunasin as soybean and triticale, we suggest that lunasin improvement in barley for functional food purposes may provide an additional value to this health-promoting cereal. Barley contains well-balanced protein, minerals, vitamins, especially vitamin $\mathrm{E}$, and 
insoluble and soluble fiber including beta-glucans, as well as much greater amounts of phenolic compounds (0.2-0.4\%) than other cereal grains. Renewed interest in barley for food uses largely focuses on the effects of beta-glucans which are found almost exclusively in barley and oats on lowering blood cholesterol levels and glycemic index (Baik and Ullrich 2008). Noteworthy, lunasin peptide also possesses antioxidant, anti-inflammatory, and cholesterol-lowering properties. Hulless barley could be of special interest because of generally higher content of beta-glucans and some other nutritionally valuable substances than covered barley and no need for dehulling and pearling for use in wholegrain foods. Unfortunately, the lunasin content in hulless variety 'Irbe' was significantly below the average.

Although barley was presumably first among the cereals used as human food, only 2-3\% of barley crop is used for food nowadays (Ullrich 2011) and can be called the most underestimated among small grain cereals. In addition to various food uses in porridges, soups, stews, flatbreads, muffins, pasta, etc., Kinner et al. (2011) have shown that the baking quality of hulless barley flour can be sufficient to bake pure hulless barley bread.

The maximal lunasin content found by us in triticale (Nakurte et al. 2012) surpassed that of barley by approximately 34-fold; therefore, the breeding of this cereal species as a functional food with an improved lunasin content is a good prospect. However, the conclusions from the present study on barley may be useful for future investigations in cereals; it is possible that the interconnections in triticale are similar to those in barley. Triticale is a good source of protein and energy and is used mainly for animal feed and very little for human consumption (Peña 2004); a little breeding effort was made for developing varieties suitable for food hitherto, but there is a potential and discovery of high lunasin content is one of the reasons to work in this direction. Barley is described as one of the most genetically diverse cereal crops (Baik and Ullrich 2008) with wide differences in physical and compositional characteristics and accordingly has different processing properties and end-use quality. Therefore, it is possible that testing a larger number of genotypes may result in the identification of barley with an even higher lunasin content.

No significant correlations between the content of lunasin and grain quality parameters such as content of crude protein, beta-glucans, thousand grain weight, and test weight or the grain yield were observed. We also did not find significant correlations between lunasin and beta-glucan content in oat (Nakurte et al. 2013) and between protein content and lunasin content in triticale, wheat, and rye (Nakurte at al. 2012). As there was no negative interconnection found, it allows to bread varieties with improved health benefit combining both high content of lunasin and beta-glucans.

\subsection{Effect of management system}

The mean lunasin content was higher by 25.0 and $18.9 \mu \mathrm{g} / \mathrm{g}$ (92 and $47 \%$ ) in the years 2010 and 2011, respectively, in the organic farming system when compared to the conventional system (Fig. 1), and the management system had a significant effect on the lunasin content (Table 4). Our results are in agreement with Wang et al. (2008), reporting that the lunasin concentration in soybean depends mainly on the genotype and, to some extent, on environmental factors. The effect of the farming system was significant in our experiment, even though only $5.2 \%$ of the difference in the lunasin content was explained by the farming system in contrast to the $68.4 \%$ for the genotype and $19.4 \%$ for the interaction between both factors. The mean lunasin content difference between both management systems in both years exceeded $100 \mu \mathrm{g} / \mathrm{g}$ for variety 'Rubiola.' 'Rubiola' was the most lunasin-rich genotype under organic management in both years, whereas line PR-4121 was prominent under conventional conditions and was the second best in the organic system, showing a maxim lunasin content throughout the experiment in 2011 $(189.0 \mu \mathrm{g} / \mathrm{g})$.

The obtained results support the value of organically grown food products for the improvement of human health, at least with regard to lunasin, as the mean lunasin content was significantly higher in the organic management system. This result is in agreement with Grinder-Pedersen et al. (2003), who noted that cereals grown in organic farming systems contain significantly more antioxidants and other biologically active substances. The possible reason for this finding can be the increased natural defense system of plants to the different stress factors that are encountered to a greater extent in organic farming, as no agrochemicals are applied and plants have to compete with weeds, diseases, and insects and to be able to uptake the nutrients from soil without supplement of easy accessible mineral fertilizers. An increase in phenolic compounds production by plants with the purpose of increasing the natural defenses is described by García-Mier et al. (2013). Additionally, Huber et al. (2011) reviewed several studies showing higher antioxidative and antimutagenic activities and better inhibition of cancer cell proliferation of organically produced foods when compared to conventionally produced foods. In our experiment, the largest differences between the systems were because of the nutrient supply and weed management. Our findings support the hypothesis that organic cereal foods may contain higher levels of phytonutrients including anticancer substances.

3.3 Genotype $\times$ management system interaction and stability

The genotype and management system interaction was found to be significant showing that there are genotypes which synthesize more lunasin under organic farming and also 


\section{Lunasin content $(\mu \mathrm{g} / \mathrm{g})$}

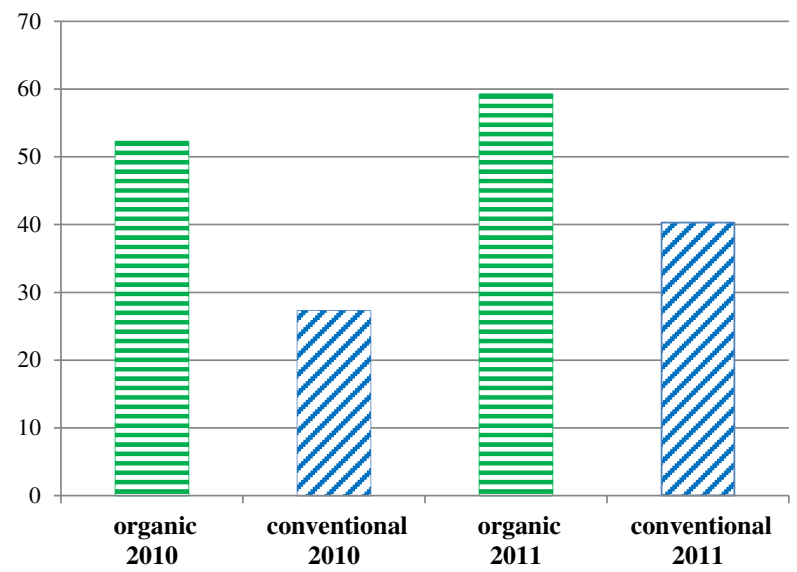

Fig. 1 Average lunasin content of 22 barley genotypes grown under organic and conventional management systems in 2010 and 2011; the difference between the management systems was significant, $\mathrm{LSD}_{0.05}=1.08$

genotypes with higher lunasin under conventional farming. Ten genotypes had a significantly higher lunasin under the organic conditions in comparison to the conventional conditions in both years, whereas varieties 'Idumeja,' 'Anni,' and line BZ14-12 with 'Anni' in its pedigree exhibited an opposite tendency; the difference for 'Idumeja' and 'Anni' was significant in 1 year only (Table 3). Similarly to our results, contrasting responses to organic practices with respect to the phytochemical content was reported by Picchi et al. (2012) for two cauliflower genotypes.

The most promising barley genotypes with a high lunasin content exclusively under organic management were 'Rubiola,' PR-4407, and PR-5145; however, only 'Rubiola' was stable over both years according to the ecovalence, but PR-5145 was highly unstable. Ecovalence measures the contribution of genotype to genotype $\times$ environment interactions; a genotype with $W_{\mathrm{i}}$ close to 0 is considered as stable (Becker and Léon 1988). 'Rubiola' is a recently registered variety with agronomic traits that are appropriate for growth in organic farming (Legzdina et al. 2008) (Fig. 2). The mean decrease of the mean lunasin content under conventional conditions was $62 \%$ for 'Rubiola' and more than $80 \%$ for breeding lines PR4407 and PR-5145. Breeding line PR-4121 and an old Lithuanian variety, 'Dziugiai,' provided comparatively high lunasin content in both farming systems. PR-4121 was relatively stable over all environments and over organic environments, but the most unstable between the years in the conventional system, whereas 'Dziugiai' was fairly stable under organic system but unstable under conventional one. We presume that the lunasin content was not influenced by the year of variety release and was not lost during the intensive breeding work performed because the other old variety 'Primus' had a low lunasin content in both systems.

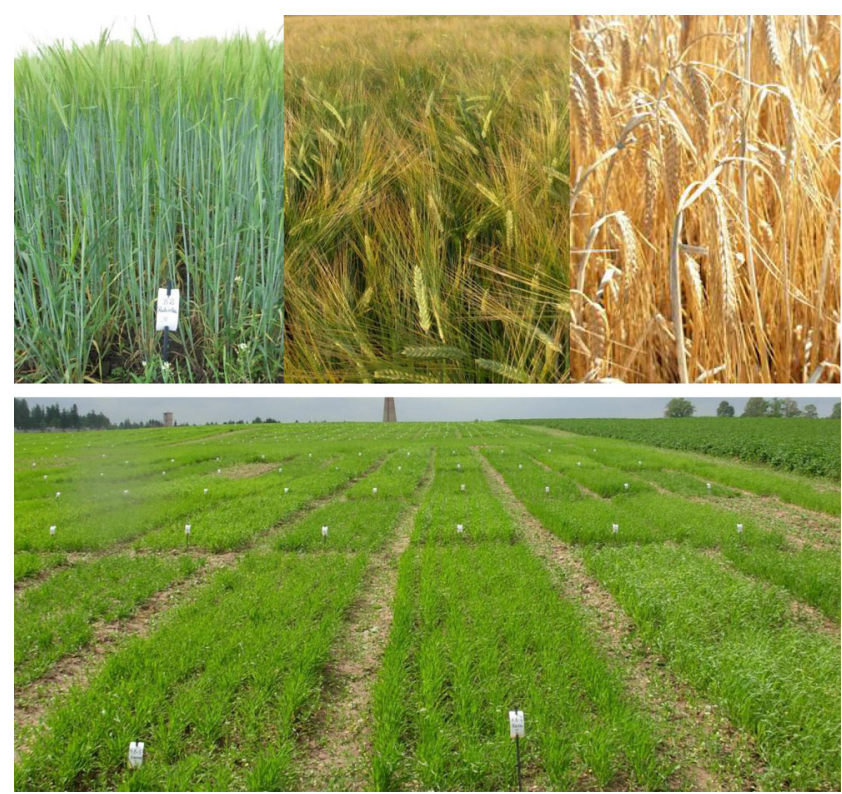

Fig. 2 Above: spring barley variety 'Rubiola' registered as appropriate for organic farming in Latvia. In the grain of 'Rubiola,' the highest lunasin content was found in trials under organic management system. Below: field experiment in organically managed field in 2011 provided the highest mean lunasin content. Photo by L. Legzdina

\subsection{Effect of the year and genotype $\times$ year interaction}

A higher mean lunasin content was found in 2011 than in 2010 in both management systems; the effect of a particular harvest year conditions including meteorological, soil, and other peculiarities on the differences in the lunasin content was significant and was estimated at $1.08 \%$. The difference between the years was notably larger under conventional conditions than under organic ones; the reduction in 2010 if compared to 2011 was 32 and $11.8 \%$, respectively. One of the possible reasons for this effect could be the unusually high incidence of Barley Yellow Dwarf Virus infection in the conventional field in 2010, as there is a possibility that this virus could hinder lunasin synthesis in the grain. However, no correlation between the lunasin content and virus infection score was found in the particular environment. No other substantial differences in environmental factors such as average temperatures, amount of precipitation and soil characteristics between the years were recorded; the vegetation period of 2011 was fairly drier if compared to 2010. Effect of temperature, soil moisture, and the interactions between these factors and the genotype were found in soybean by Wang et al. (2008); significant effects of genotype $\times$ environment interactions were reported in respect to other biologically active chemicals in cereals, e.g., 5- $n$ alkylresorcinols and free phenolics in durum wheat (Bellato et al. 2013) and vitamin E isomers in barley (Ehrenbergerová et al. 2006). Genotype × year and genotype $\times$ management system $\times$ year interactions were also significant and explained 2.21 and $3.22 \%$ of the differences in lunasin content, respectively. Two genotypes 
with high lunasin content, PR-4121 and 'Dziugiai,' showed opposite reaction to the management systems in both years.

To summarize, our findings provide new information on variation of lunasin in barley grain, proves higher average lunasin content in organically grown grain, and shows that the reaction of barley genotypes to organic and conventional management and to the environmental factors of the year in connection with the synthesis of lunasin in the grain can be different.

\section{Conclusions}

The lunasin content in barley grain samples ranged from 5.0 to $189.0 \mu \mathrm{g} / \mathrm{g}$. The effects of the genotype, crop management system, year, and the interaction between the factors on the lunasin content in barley grain were significant with the largest proportion of genotype. The mean lunasin content was higher under organic management than that in the conventional system. The barley genotypes responded differently to the management system: 10 of the 22 genotypes synthesized significantly more lunasin under organic management in both years, whereas one genotype synthesized more lunasin under conventional management and two genotypes had conversely results between the years.

Acknowledgments This research was supported by European Social Found co-financed project Nr. 2009/0218/1DP/1.1.1.2.0/09/APIA/VIAA/ 099. The authors thank Aina Kokare for the help in data statistical analysis.

\section{References}

Baik BK, Ullrich SE (2008) Barley for food: characteristics, improvement, and renewed interest. J Cer Sci 48:233-242. doi:10.1016/j.jcs. 2008.02.002http

Becker HC, Léon J (1988) Stability analysis in plant breeding. Plant Breed 101:1-23

Bellato S, Ciccoritti R, Del Frate V, Sgrulletta D, Carbone K (2013) Influence of genotype and environment on the content of 5-n alkylresorcinols, total phenols and on the antiradical activity of whole durum wheat grains. J Cer Sci 57:162-169

Benbrook CM (2005) Elevating antioxidant levels in food through organic farming and food processing. The Organic Center for Education and Promotion. http://www.organic-center.org/ reportfiles/Antioxidant SSR.pdf. Accessed 10 Oct 2012

Bour D, Prescott J (2002) Comparison of the nutritional value, sensory qualities, and food safety of organically and conventionally produced foods. Crit Rev Food Sci Nutr 42:1-34. doi:10.1080/ 10408690290825439

Cam A, Sivaguru M, Gonzalez de Mejia E (2013) Endocytic mechanism of internalization of dietary peptide lunasin into macrophages in inflammatory condition associated with cardiovascular disease. PLoS One 5:8. doi:10.1371/journal.pone.0072115

Carbonaro M, Mattera M (2001) Polyphenoloxidase activity and polyphenol levels in organically and conventionally grown peach (Prunus persica L., cv. Regina bianca) and pear (Pyrus communis L., cv. Williams). Food Chem 72:419-424. doi:10.1016/S03088146(00)00248-X de Lumen BO (2005) Lunasin: a cancer-preventive soy peptide. Nutr Rev 63:16-21. doi:10.1301/nr.2004.janr.16-21

de Mejia EG, Vasconez M, de Luman BO, Nelson R (2004) Lunasin concentration in different soybean genotypes, commercial soy protein, and isoflavone products. J Agric Food Chem 52:5882-5887. doi:10.1021/jf0496752

Dzirkale Z, Rumaks J, Svirskis S, Mazina O, Allikalt A, Rinken A, Jekabsons K, Muceniece R, Klusa V (2013) Lunasin-induced behavioural effects in mice: focus on the dopaminergic system. Behav Brain Res 256:5-9. doi:10.1016/j.bbr.2013.08.002

Ehrenbergerová J, Belcrediová N, Prýma J, Vaculová K, Newman CW (2006) Effect of cultivar, year grown, and cropping system on the content of tocopherols and tocotrienols in grains of hulled and hulless barley. Plant Foods Hum Nutr 61:145-150

Galvez AF, de Lumen BO (1999) A soybean cDNA encoding a chromatin-binding peptide inhibits mitosis of mammalian cells. Nat Biotechnol 17:495-500. doi:10.1038/8676

García-Mier L, Guevara-González RG, Mondragón-Olguín VM, Verduzco-Cuellar BR, Torres-Pacheco I (2013) Agriculture and bioactives: achieving both crop yield and phytochemicals. Int $\mathrm{J}$ Mol Sci 14:4203-4222. doi:10.3390/ijms14024203

Grinder-Pedersen L, Rasmussen SE, Bügel S, Jørgensen LV, Dragsted LO, Gundersen V, Sandström B (2003) Effect of diets based on foods from conventional versus organic production on intake and excretion of flavonoids and markers of antioxidative defense in humans. J Agric Food Chem 51:5671-5676. doi:10.1021/jf030217n

Hernández-Ledesma B, Hsieh CC, de Lumen BO (2009) Lunasin, a novel seed peptide for cancer prevention. Pept 30:426-430. doi: 10.1016/j.peptides.2008.11.002

Hernández-Ledesma B, Hsieh CC, de Lumen BO (2013) Chemopreventive properties of peptide lunasin: a review. Protein Pept Lett 20:424-432. doi:10.2174/092986613805290327

Huber M, Rembiałkowska E, Średnicka D, Bügel S, van de Vijver LPL (2011) Organic food and impact on human health: assessing the status quo and prospects of research. NJAS-Wagen. J Life Sci 58: 103-109

Jeong HJ, Lam Y, de Lumen BO (2002) Barley lunasin suppresses rasinduced colony formation and inhibits core histone acetylation in mammalian cells. J Agric Food Chem 50:5903-5908. doi:10.1021/ jf0256945

Jeong HJ, Jeong JB, Kim DS, Park JH, Lee JB, Kweon DH, Chung GY, Seo EW, de Lumen BO (2007a) The cancer preventive peptide lunasin from wheat inhibits core histone acetylation. Cancer Lett 255:42-48. doi:10.1016/j.canlet.2007.03.022

Jeong JB, Jeong HJ, Park JH, Lee SH, Lee JR, Lee HK, Chung GY, Choi JD, de Lumen BO (2007b) Cancer-preventive peptide lunasin from Solanum nigrum L. inhibits acetylation of core histones $\mathrm{H} 3$ and $\mathrm{H} 4$ and phosphorylation of retinoblastoma protein $(\mathrm{Rb})$. J Agric Food Chem 55:10707-10713. doi:10.1021/jf072363p

Jeong HJ, Lee JR, Jeong JB, Park JH, Cheong Y, de Lumen BO (2009) The cancer preventive seed peptide lunasin from rye is bioavailable and bioactive. Nutr and Cancer 61:680-686. doi:10.1080/ 01635580902850082

Jeong HJ, Jeong JB, Hsieh CC, Hernández-Ledesma B, de Lumen BO (2010a) Lunasin is prevalent in barley and is bioavailable and bioactive in in vivo and in vitro studies. Nutr Cancer 62:11131119. doi:10.1080/01635581.2010.515529

Jeong JB, De Lumen BO, Jeong HJ (2010b) Lunasin peptide purified from Solanum nigrum L. protects DNA from oxidative damage by suppressing the generation of hydroxyl radical via blocking fenton reaction. Cancer Lett 293:58-64. doi:10.1016/j

Kinner M, Nitschko S, Sommeregger J, Petrasch A, Linsberger-Martin G, Grausgruber H, Berghofer E, Siebenhandl-Ehn S (2011) Naked barley-optimized recipe for pure barley bread with sufficient betaglucan according to the EFSA health claims. J Cereal Sci 53:225230. doi:10.1016/j.jcs.2011.01.001 
Koh E, Wimalasiri KMS, Renaud ENC, Mitchel AE (2008) A comparison of flavonoids, carotenoids and vitamin $\mathrm{C}$ in commercial organic and conventional marinara pasta sauce. J Sci Food Agric 88:344 354. doi:10.1002/jsfa.3097

Legzdiņa L, Gaiķe M, Gaile Z, Bērziña I (2008) Testing results of spring barley variety 'Rubiola'. Latv J Agron 11:94-101

Lombardo S, Pandino G, Mauromicale G (2012) Nutritional and sensory characteristics of "early" potato cultivars under organic and conventional cultivation systems. Food Chem 133:1249-1254. doi:10. 1016/j.foodchem.2011.10.005

Magkos F, Arvaniti F, Zampelas A (2003) Organic food: nutritious food or food for thought? A review of the evidence. Int J Food Sci Nutr 54:357-371. doi:10.1080/09637480120092071

Murniece I, Kruma Z, Skrabule I (2012) Carotenoids and colour before and after storage of organically and conventionally cultivated potato genotypes in Latvia. World Acad Sci Eng Technol 67:1201-1205

Nakurte I, Klavins K, Kirhnere I, Namniece J, Adlere L, Matvejevs J, Kronberga A, Kokare A, Strazdina V, Legzdina L, Muceniece R (2012) Discovery of lunasin peptide in triticale (X Triticosecale Wittmack). J Cereal Sci 56:510-514. doi:10.1016/j.jcs.2012.04.004

Nakurte I, Kirhnere I, Namniece J, Saleniece K, Krigere L, Mekss P, Vicupe Z, Bleidere M, Legzdina L, Muceniece R (2013) Detection of the lunasin peptide in oats (Avena sativa L.). J Ceral Sci 57:319324. doi:10.1016/j.jcs.2012.12.008

Park JH, Jeong HJ, de Lumen BO (2005) Contents and bioactivities of lunasin, Bowman-Birk inhibitor, and isoflavones in soybean seed. $\mathrm{J}$ Agric Food Chem 53:7686-7690

Peña RJ (2004) Food uses of triticale. In: Mergoum M, GómezMacpherson H (eds), Triticale improvement and production. FAO
Plant Production and Protection Paper 179, pp 37-49. ftp://ftp.fao. org/docrep/fao/009/y5553e/y5553e01.pdf. Accessed 18 Nov 2013

Picchi V, Migliori C, Scalzo RL, Campanelli G, Ferrari V, Di Cesare LF (2012) Phytochemical content in organic and conventionally grown Italian cauliflower. Food Chem 130:501-509. doi:10.1016/j. foodchem.2011.07.036

Silva-Sánchez C, de la Rosa AP, León-Galván MF, de Lumen BO, de León-Rodríguez A, de Mejía EG (2008) Bioactive peptides in amaranth (Amaranthus hypochondriacus) seed. J Agric Food Chem 56:1233-1240. doi:10.1021/jf072911z

Smith-Spangler C, Brandeau ML, Hunter GE, Bavinger JC, Pearson M, Eschbach PJ, Sundaram V, Liu H, Schirmer P, Stave C, Olkin I, Bravata DM (2012). Are organic foods safer or healthier than conventional alternatives?: a systematic review. Ann Intern Med 157:348-366. doi:10.7326/0003-4819-157-5-201209040-00007 DOI:10.7326\%2F0003-4819-157-5-201209040-00007

Ullrich SE (2011) Significance, adaptation, production, and trade of barley. In: Ullrich SE (ed) Barley: production, improvement, and uses. Wiley-Blackwell, Ames, pp 3-13

Wang W, Dia VP, Vasconez M, de Mejia EG, Nelson RL (2008) Analysis of soybean protein-derived peptides and the effect of cultivar, environmental conditions, and processing on lunasin concentration in soybean and soy products. J AOAC Int 91:936-946

Woese K, Lange D, Boess C, Bögl KW (1997) A comparison of organically and conventionally grown foods - results of a review of the relevant literature. J Sci Food Agric 74:281-293. doi:10.1002/ (SICI)1097-0010(199707)74:3<281::AID-JSFA794>3.0.CO;2-Z

Worthington V (2001) Nutritional quality of organic versus conventional fruits, vegetables, and grains. J Altern Complement Med 7:161-173 